\title{
ANALISIS KEKUATAN ALAT BUKTI TIDAK LANGSUNG DALAM PEMBUKTIAN DUGAAN PRAKTIK KARTEL
}

\author{
Wahyu Dwi Erlangga, Arrisman; Universitas Pembangunan Nasional Veteran Jakarta, \\ Jl. R.S Fatmawati Pondok Labu Jakarta Selatan, Email: wahyudwierlangga@gmail.com \\ Email: arrisman.dr@gmail.com
}

\begin{abstract}
Abstrak
Komisi Pengawas Persaingan Usaha (KPPU) dalam menangani praktik kartel menggunakan pembuktian tidak langsung (indirect evidence) karena para pelaku usaha menggunakan perjanjian secara rahasia atau diam-diam sehingga sulit dibuktikan secara langsung. Praktiknya dalam proses penegakan hukum perkara kartel yang ditangani oleh KPPU maupun peradilan serta Mahkamah Agung terdapat inkonsistensi atau perbedaan pertimbangan hukum terkait keabsahan pembuktian tidak langsung. Melalui penelitian yuridis normatif dengan menggunakan data sekunder, peneliti ingin mengetahu tentang pembuktian kasus kartel oleh KPPU jika tidak ditemukan alat bukti langsung dan kedudukan alat bukti tidak langsung (circumstantial evidence) dalam Undang-Undang Nomor 5 Tahun 1999 tentang Larangan Praktik Monopoli dan Persaingan Usaha Tidak Sehat, menghasilkan penelitian bahwa KPPU dalam menggunakan pembuktian tidak langsung dilakukan karena dalam praktik kartel perjanjian dilakukan secara diam-diam maupun rahasia, praktiknya dalam Putusan Mahkamah Agung masih terdapat penafsiran atas pembuktian tidak langsung yang belum mengatur keabsahan sebagaimana di dalam UU Larangan Praktik Monopoli dan Persaingan Usaha Tidak Sehat. Kedudukan alat bukti tidak langsung seperti bukti komunikasi dan bukti ekonomi sebagai alat bukti tidak langsung berbeda dengan alat bukti lain baik dalam perdata maupun pidana karena kedudukan bukti tidak langsung hanya sebagai petunjuk serta bukti tambahan pendukung dalam mencari kebenaran materiil praktik monopoli.
\end{abstract}

Kata Kunci : Kartel, Monopoli, Pembuktian Tidak Langsung.

\section{Abstract}

In dealing with Cartel Practices, KPPU uses indirect evidence because business actors use agreements secretly or secretly so it is difficult to prove it directly. In practice, in the process of law enforcement in cartel cases handled by the KPPU and the judiciary and the Supreme Court, there are inconsistencies or differences in legal considerations related to the validity of indirect evidence. The formulation of this problem is how is the evidence of a cartel case by the Business Competition Supervisory Commission (KPPU) if direct evidence is not found and what is the position of indirect evidence (circumstantial evidence) in Law No. 5 of 1999 concerning the prohibition of monopolistic and unfair business competition. This research method uses normative juridical research using secondary data. The result of the research is that KPPU uses indirect evidence because in the cartel practice the agreement is carried out secretly or in secret. In practice, there is still an interpretation of indirect evidence in the Supreme Court Decision that has not regulated its validity as in Law No. 5 of 1999. The position of indirect evidence such as communication evidence and economic evidence as indirect evidence is different from other evidence both in civil and criminal cases because the position of indirect evidence is only as evidence and additional supporting evidence in seeking the material truth of monopolistic practices.

Keywords: Cartel, Monopoly, Indirect Evidence

\section{PENDAHULUAN}

\section{Latar Belakang}

Aktivitas dalam menjalankan bisnis terutama untuk kepentingan komersil dari para pelaku usaha dalam aktivitasnya melakukan persaingan usahanya, dilakukan agar usahanya memproduksi atau memasarkan barang atau jasa diminati oleh masyarakat sebagai konsumen, juga memberikan manfaat di dalam masyarakat guna mencapai 
tujuan mendayagunakan sumber daya serta peningkatan ekonomi secara optimal. ${ }^{1}$ Namun terkadang pelaku usaha melakukan monopoli yang menjadikan kekayaan hanya ditangan segelintir pelaku usaha yang berbuat curang dan berdampak terjadinya kesenjangan ekonomi maupun sosial. ${ }^{2}$

Pengaruh adanya monopoli di suatu negara dengan adanya pemusatan kekuatan sumber daya ekonomi bahkan lebih dari separuh pangsa pasar dikendalikan, mempengaruhi konsumen yang mempunyai pilihan sangat terbatas atas suatu produk barang ataupun jasa yang sudah ditentukan dan ditetapkan terhadap pihak pelaku usaha yang melakukan monopoli. ${ }^{3}$ Salah satu perjanjian antara satu perusahaan dengan perusahaan lain dalam bentuk persengkongkolan kartel secara langsung ataupun tidak langsung dapat mempengaruhi mekanisme pasar. Para pelaku usaha yang terikat dalam suatu kartel praktiknya terdiri dari sekumpulkan perusahaan yang besar dengan menghasilkan produk-produk yang sejenis dan tujuan sendiri digunakan untuk pengendalian harga, sehingga dengan harga yang terbentuk dan disesuaikan dampaknya harga yang terbentuk bukanlah harga yang bersaing (competitive price). 4

Norma ketentuan bagi larangan terhadap kartel di Indonesia, telah diatur dalam ketentuan pasal 11 Undang-Undang Nomor 5 Tahun 1999 tentang Larangan Praktik Monopoli dan Persaingan Usaha Tidak Sehat (selanjutnya disebut UU 5/1999) yang menyatakan pelaku usaha dalam kegiatan usahanya dilarang untuk melakukan perjanjian dengan sesama pelaku usaha pesaingnya, dengan maksud mempengaruhi harga dan mengatur produksi atau pemasaran barang atau jasa yang mengakibatkan terjadinya praktek monopoli dan atau persaingan usaha tidak sehat.

Perjanjian penetapan harga (price fixing) sebagaimana ketentuan Pasal 11 UU 5/1999 yakni suatu kesepakatan penetapan harga yang sama oleh pelaku usaha dengan pelaku usaha lainnya yang juga sering disebut pesaing. Pada praktiknya, perjanjian kartel yang dimaksud digunakan untuk meningkatkan harga sehingga perolehan keuntungan dari penjualan semakin meningkat. Indikasi praktik kartel juga terjadi adanya keseragaman harga yang diawali dengan kelangkaan pemasokan barang atau jasa, sehingga terbentuk harga yang sangat tinggi dan memaksa konsumen untuk produk tersebut dengan harga yang lebih mahal sebagaimana mestinya. ${ }^{5}$

${ }^{1}$ Mustafa Kamal Rokan. (2010). Hukum Persaingan Usaha (Teori dan Praktiknya di Indonesia), Jakarta: Raja Grafindo Persada, h. 1.

${ }^{2}$ Meita Fadhilah. (2019). "Penegakan Hukum Persaingan Usaha Tidak Sehat oleh Komisi Pengawas Persaingan Usaha (KPPU) dalam Kerangka Ekstrateritorial". Wawasan Yuridika, Vol. 3, No.1, Maret 2019, h. 56.

${ }^{3}$ Maya Meilia. (2019). "Persaingan Usaha Tidak Sehat di Indonesia Menurut Hukum Ekonomi Islam di Indonesia Menurut Hukum Ekonomi Islam dan Undang-Undang Nomor 5 Tahun 1999 tentang Larangan Monopoli dan Persaingan Usaha Tidak Sehat". Jurnal Ekonomi Islam, Vol. 7. No. 1, Januari-Juni 2019, h. 22.

"Supriatna. (2016). "Persengkokolan Bisnis dalam Bentuk Perjanjian Kartel”, Positum, Vol. 1., No. 1, Desember 2016, h. 125.

5Parida Angriani, (2016), Indikasi Kartel Komunditas Strategis Dalam Perspektif Hukum Persaingan Usaha Tidak Sehat (Studi Kajian Perlindungan Hukum), Dialogia Juridica Jurnal Hukum Bisnis dan Investasi, Vol. 7, No. 2, April 2016, h. 25. 
Praktiknya dalam penegakan hukum anti monopoli dan persaingan usaha tidak sehat kartel dianggap salah satu bentuk tindakan kolutif oleh para pelaku usaha yang dianggap sebagai pelanggaran berat karena dampaknya terhadap penurunan social welfare state, nampak terlihat jelas, karena besarnya kerugian yang diterima oleh masyarakat sebagai konsumen. ${ }^{6}$

Pada proses penegakan hukum bagi para pelaku usaha yang melakukan praktik kartel maka upaya yang dilakukan oleh Komisi Pengawas Persaingan Usaha (KPPU) yang mana harus membuktikan terhadap ketentuan Unsur Pasal 11 UU 5/1999, apakah pihak pelaku usaha telah melawan hukum dalam melakukan perjanjian yang dilarang dalam bentuk kartel yang menimbulkan praktik monopoli, namun praktiknya kartel yang dilakukan biasanya dibentuk dan dilakukan secara rahasia maka pembuktian perjanjian kartel menimbulkan permasalahan. ${ }^{7}$

Kedudukan KPPU tentunya akan sulit untuk menemukan adanya perjanjian tertulis maupun dokumen lain yang secara kontekstual berisi kesepakatan mengenai harga, wilayah pemasaran dan produksi atas barang dan/atau jasa bagi pelaku usaha yang terikat dalam perjanjian kartel. Maka salah satunya cara untuk membuktikan adanya pelanggaran pelaku usaha yang diduga melakukan kartel dengan cara alat bukti tidak langsung (indirect evidence). ${ }^{8}$

Pembuktian hukum yang dilakukan oleh KPPU untuk mendapat bukti langsung berupa perjanjian dalam praktik kartel, kenyataanya memang sangat sulit untuk didapatkan, namun tetap harus dilakukan karena satu-satunya cara untuk mengungkap adanya perilaku pelaku usaha yang melawan hukum dengan cara membuktikan secara tidak langsung, namun alat bukti untuk memperolehnya sangat terbatas dan tidak secara langsung terdiskripsikan dalam perjanjian kartel, namun bisa juga dengan bentuk fasilitas lain, atau pertukaran informasi.

Mengacu UU 5/1999 saat ini Indonesia belum mengatur tentang pembuktian tidak langsung sebagai alat bukti untuk membuktikan terjadinya kartel. KPPU dalam hal ini membuktikan dengan mencari kebenaran materiil sebagaimana ketentuan di dalam Pasal 42 berkaitan dengan alat bukti yaitu keterangan saksi, keterangan ahli, surat dan atau dokumen, petunjuk, dan keterangan pelaku usaha, dalam hal ini pembuktian yang diutamakan oleh KPPU pada umumnya dilakukan secara langsung (circumstantial evidence) dengan melihat adanya perjanjian kesepakatan yang dilakukan dalam bentuk kartel..$^{9}$

${ }^{6}$ Veri Antoni. (Mei 2019). Penegakan Hukum Atas Perkara Kartel Di Luar Persekongkolan Tender Di Indonesia, Mimbar Hukum, Vol. 31., No. 1, h. 97-98.

${ }^{7}$ Udin Silalahi, (2011), Mengungkap Kartel dengan Bukti Langsung, Jakarta: Asean Competition Institute, h. 11.

${ }^{8}$ Udin Silalahi dan Isabella Cynthia Edgina. (Desember 2017). Pembuktian Perkara Kartel Di Indonesia Dengan Menggunakan Tidak Langsung (Indirect Evidence) Kajian Putusan KPPU Nomor 17/KPPUI/2010 dan Nomor 08/KPPU-I/2004 serta Putusan Nomor 294 K/Pdt.Sus/2012 dan Nomor 221 K/Pdt.SusKPPU/2016, Jurnal Yudisial, Vol. 10, No. 3, h. 313.

9Ibnu Akhyat. (Oktober 2018). Penggunaan Indirect Evidence (Alat Bukti Tidak Langsung) Dalam Proses Pembuktian Dugaan Praktik Kartel di Indonesia oleh KPPU, Era Hukum, Vol. 16, No. 2, h. 351. 
Praktiknya dalam beberapa kasus kartel, KPPU menggunakan pembuktian secara tidak langsung, dapat dilihat dalam perkara Putusan KPPU Nomor 24/KPPU-I/2009 dengan 21 (dua puluh satu) Perusahaan Swasta yang melakukan kegiatan di pasar minyak curah yang berdasarkan hasil temuan KPPU telah melakukan pelanggaran kartel, yang mana dalam pembuktian dilakukan pembuktian secara tidak langsung (indirect evident), dengan cara mengumpulkan alat bukti komunikasi (communication evidence), dan bukti ekonomi (economics evidence) dan Facilitating practices. Putusan KPPU telah menyatakan ke 21 (dua puluh satu) perusahaan swasta tersebut dalam kegiatan pasar minyak curah telah melakukan kartel yang termasuk dalam unsur praktek monopoli dan atau persaingan usaha. Namun ketentuan dari Putusan KPPU tersebut telah dibatalkan oleh Putusan Pengadilan Negeri Nomor 03/KPPU-I/2010/PN.JKT.PST yang dikuatkan dengan Putusan Kasasi Mahkamah Agung Nomor 582 K/Pdt.Sus/2011.

Perkara lain yang diputus dalam KPPU Nomor 08/KPPU-I/2014 berkaitan dengan dugaan pelanggaran kartel dalam industry Otomotif terkait Kartel Ban Kendaraan Bermotor Roda Empat yang dilakukan 6 (enam) Perusahaan yang melakukan koordinasi penentuan harga antar perusahaan pada industri ban, Adapun KPPU dalam investigasinya melakukan pembuktian tidak langsung (indirect evident) dengan melihat adanya tukar informasi dan risalah APBI sehingga putusan KPPU menyatakan para perusahaan ban kendaraan bermotor roda empat telah melanggar ketentuan Pasal 11 UU No. 5 Tahun 1999. Kemudian perkara selanjutnya yang juga diputus oleh KPPU Nomor Nomor 04/KPPU-I/2016 berkaitan dengan praktik monopoli atas kartel yang dilakukan oleh PT. Yamaha Indonesia Motor Manufacturing (selanjutnya disebut dengan "Yamaha") dan PT. Astra Honda Motor (selanjutnya disebut dengan "Honda") yang melakukan pertemuan untuk membicarakan kesediaan Yamaha akan mengikuti harga jual motor dari Motor Honda yang akhirnya terdapat penyesuaian harga jual produk Sepeda Motor Jenis Skuter Matik 110-125 CC di Indonesia.

Berdasarkan kasus-kasus kartel ini terdapat inkonsisten dalam penerimaan bukti tidak langsung sebagai alat bukti dalam pembuktian praktik kartel, dan secara norma dan praktik juga perlu adanya kepastian hukum bagi penegak hukum dalam pelaksanaan pembuktian tidak langsung dalam kasus kartel, maka dalam hal ini peneliti mengangkat jurnal penelitian ini yang berjudul "Analisis Kekuatan Alat Bukti Tidak Langsung dalam Pembuktian Dugaan Praktik Kartel”.

\section{Rumusan Masalah}

Berdasarkan latar belakang masalah tersebut di atas, sehingga dapat dirumuskan suatu rumusan masalah yang diteliti yakni sebagai berikut:

1. Bagaimanakah pembuktian kasus kartel oleh Komisi Pengawas Persaingan Usaha (KPPU) jika tidak ditemukan alat bukti langsung (direct evidence) ?

2. Bagaimanakah kedudukan alat bukti tidak langsung (circumstantial evidence) dalam Undang-Undang No. 5 Tahun 1999 tentang Larangan Praktik Monopoli Dan Persaingan Usaha Tidak Sehat? 


\section{METODE PENELITIAN}

Penelitian ini menggunakan metode penelitian yuridis normatif mengacu pada norma-norma dan asas-asas hukum yang terdapat dalam Undang-Undang Nomor 5 Tahun 1999 tentang Larangan Praktik Monopoli dan Tidak Persaingan Usaha Tidak Sehat (UU 5/1999) dan ketentuan hukum yang terkait serta putusan pengadilan dalam praktik pembuktian kasus kartel di Indonesia.

Sumber data yang digunakan menggunakan data sekunder ${ }^{10}$ yang terdiri dari bahan hukum primer berupa Kitab Undang-Undang Hukum Perdata (KUH Perdata. Herzien Indlandsch Reglement (H.I.R) Reglemen Indonesia yang diperbaharui (R.IB.), Undang-Undang Nomor 8 Tahun 1981 tentang Kitab Undang-Undang Hukum Acara Pidana, Undang-Undang Nomor 5 Tahun 1999 tentang Larangan Praktek Monopoli dan Persaingan Usaha Tidak Sehat, Peraturan Komisi Pengawas Persaingan Usaha Nomor 4 Tahun 2010 tentang Kartel, Putusan Komisi Pengawas Persaingan Usaha (KPPU) Republik Indonesia Perkara Nomor 24/KPPU-1/2009, Putusan Komisi Pengawas Persaingan Usaha Republik Indonesia Perkara Nomor 08/KPPU-I/2014, Putusan Komisi Pengawas Persaingan Usaha Republik Indonesia Perkara Nomor 04/KPPU-I/2016, Putusan Pengadilan Negeri Jakarta Pusat Nomor 03/KPPU-I/2010/PN.JKT.PST dan Putusan Perkara Kasasi Mahkamah Agung Nomor 582 K/Pdt.Sus/2011, dan Putusan Kasasi Mahkamah Agung Nomor 495 K/Pdt.Sus-KPPU/2017, bahan hukum sekunder yaitu bahan yang memberikan penjelasan mengenai bahan hukum primer, seperti bukubuku, rancangan undang-undang, hasil-hasil penelitian, atau pendapat pakar hukum tentang praktik monopoli dan persaingan usaha tidak sehat dalam penelitian ini tentang pembuktian praktik kartel di Indonesia dan bahan hukum tersier yaitu bahan hukum yang memberikan informasi maupun petunjuk terhadap bahan hukum primer dan bahan hukum sekunder seperti kamus hukum maupun wikipedia.

Penelitian hukum normatif ini bersifat deskriptif dengan pendekatan perundangundangan (statute approach) yakni ketentuan yang diatur di dalam norma hukum UU 5/1999 dan KUH Perdata tentang kartel dan pembuktian hukumnya serta pendekatan kasus (case approach), beberapa perkara di Komisi Pengawas dan Persaingan Usaha (KPPU) dan Putusan Mahkamah Agung tentang pembuktian kartel. ${ }^{11}$ Teknik analisis yang digunakan mengggunakan pendekatan analisis kualitatif, dengan sumber data dari kumpulan literatur buku-buku dan artikel jurnal, makalah yang yang diteliti dan ditulis oleh akademisi dan praktisi hukum monopoli dan persaingan usaha tidak sehat serta ketentuan dalam ketentuan hukum perdata tentang pembuktian perjanjian kartel yang dilarang.

\footnotetext{
${ }^{10}$ Amiruddin dan Zainal Asikin, (2010), Pengantar Metode Penelitian Hukum, Jakarta: PT Raja Grafindo, h. 118-119.

11Suratman dan Philips Dillah, (2010), Metode Penelitian Hukum, Malang: Alfabeta, h. 55.
} 


\section{PEMBAHASAN}

\section{A. Pembuktian Kasus Kartel oleh Komisi Pengawas Persaingan Usaha (KPPU) Jika Tidak Ditemukan Alat Bukti Langsung (Direct Evidence)}

KPPU dalam melakukan pembuktiannya memiliki kewenangan untuk melakukan penegakan hukum dalam perkara kartel baik inisiatif KPPU sendiri atau atas dari laporan dari masyarakat sebagaimana ketentuan Pasal 36 UU 5/1999.12 Kedudukan hukum sebagai lembaga yang dibentuk oleh negara untuk menangani berbagai pelanggaran praktik monopoli dan persaingan usaha tidak sehat, yang mana KPPU menangani perkara berdasarkan laporan yang masuk ke KPPU atau berdasarkan inisiatif sendiri dalam melihat situasi dunia persaingan usaha. Penegakan hukum yang dilakukan oleh KPPU yang paling banyak ditemukan salah satunya adalah kartel, yang mana penanganan perkara tersebut telah melalui pemeriksaan dan sidang majelis KPPU, yang mana keputusannya bersifat mengikat namun tidak final karena masih dimungkinkan bagi pihak yang terlapor dapat mengajukan keberatan ke pengadilan negeri hingga di tingkat kasasi Mahkamah Agung. ${ }^{13}$

Kewenangan KPPU selain dalam memutus perkara kasus praktik monopoli dan persaingan usaha tidak sehat, namun juga dapat melakukan penyelidikan dari hasil penelitian yang dilakukannya sebagaimana ketentuan Pasal 36 UU 5/1999 guna mencari kebenaran materiil dengan cara mengumpulkan alat bukti atau pembuktian atas dugaan pelanggaran kasus praktik monopoli. Pembuktian sangat penting digunakan dan dilakukan oleh KPPU karena merupakan keseluruhan aturan hukum yang diatur dalam peraturan perundang-undangan untuk melakukan rekonstruksi suatu kenyataan yang benar yang terjadi di masa lalu dan relevan dengan persangkaan terhadap pelanggaran atau perbuatan yang dilakukannya. ${ }^{14}$ Teori dalam hukum pembuktian menurut Subekti yang dimaksudkan adalah meyakinkan hakim tentang adanya suatu kebenaran dalil-dalil yang dikemukakan oleh para pihak yang bersengketa dan memberikan kepastian terhadap hakim tentang adanya peristiwa-peristiwa tertentu untuk hakim dapat mengambil suatu keputusan yang menurutnya benar..$^{15}$

Pembuktian dalam praktik monopoli yang dilakukan oleh KPPU mengenal adanya (2) dua pendekatan dalam penerapan hukumnya yakni pendekatan perse illegal dan pendekatan rule of reason. Dalam konsep pembuktian kedua pendekatan tersebut dapat dilihat apakah pelaku usaha harus dihukum dalam melakukan suatu perbuatan dalam alasan perbuatan tersebut dianggap membahayakan persaingan dalam usaha termasuk

\footnotetext{
${ }^{12}$ Made Prasasta Primandhika dan I Gede Artha. (Juli 2019). Analisis Penerapan Pendekatan Rule Of Reason Dan Per Se Ilegal Terhadap Kasus Kartel di Indonesia, Kertha Semaya: Journal Ilmu Hukum, Vol. 6. No. 7, h. 2.

${ }^{13}$ Alum Simbolon. (Oktober 2012). Kedudukan Hukum Komisi Pengawas Persaingan Usaha Melaksanakan Wewenang Penegakan Hukum Persaingan Usaha, Mimbar Hukum, Vol. 23, No. 3, h. 535536.

${ }^{14}$ Fira Mubayyinah. (Maret 2017). Perbandingan Sistem Hukum Pembuktian dalam Penanganan Perkara Tindak Korupsi Dengan Perkara Tindak Pidana Lainnya, Al Hikmah Jurnal Studi Keislaman, Vol. 7, No. 1, h. 38.

${ }^{15}$ Ali Imron dan Muhamad Iqbal, (2019), Hukum Pembuktian, Tangerang: UNPAM PRESS, h. 2.
} 
konsumen. Larangan yang bersifat per se yakni larangan yang bersifat mutlak dan jelas terhadap perbuatan atau perjanjian dalam kepastian kepada pelaku usaha, dalam hal ini perjanjian yang dilarang secara per se berarti dipastikan perbuatan tersebut akan merusak atau menghilangkan persaingan sebaliknya dalam pendekatan rule of reason yakni suatu perbuatan yang dilakukan oleh pelaku pelaku usaha melihat dampak yang signifikan menggangu dan menghambat persaingan maka akan diambil tindakan hukum. ${ }^{16}$ Maka dapat dilihat pembuktian dengan pendekatan rule of reason dalam praktik monopoli rule of reason, tidak mudah dilakukan karena harus melakukan penelitian dan pembuktian yang luas untuk dapat menyatakan bahwa pelaku usaha tersebut telah melakukan praktik monopoli dan persaingan usaha tidak sehat.

Dalam praktik kartel yang dilarang dilakukan berdasarkan ketentuan Pasal 11 UU 5/1999 dilihat dari perjanjian pada umumnya dapat dikatakan kartel merupakan perjanjian yang dilarang karena praktik kartel sangat merugikan masyarakat dengan cara mempengaruhi harga dengan mengatur produksi dan/atau pemasaran suatu barang dan atau jasa yang bisa mengakibatkan praktik monopoli dan persaingan usaha tidak sehat, sehingga perjanjian tersebut haruslah dibatalkan secara objektivitas sebagaimana ketentuan yang diatur dalam Pasal 1320 KUH Perdata yang menyatakan dalam syaratsyarat perjanjian harus memenuhi suatu kesepakatan, cakap dalam membuat perjanjian, suatu hal-hal tertentu berkaitan dengan objek yang diperjanjikan dan suatu sebab klausula yang halal. Perjanjian kartel dapat dikategorikan suatu klausula yang tidak halal karena dalam perjanjian yang dibuat oleh para pelaku usaha secara norma harus tidak bertentangan dengan ketertiban umum, itikad baik, kepatutan dengan kebiasaan yang mana ketentuan tersebut dipertegas di dalam Pasal 1338 juncto Pasal 1339 KUH Perdata.

Praktik kartel menurut Susanti Adi Nugroho yaitu kerjasama dari produsenprodusen produk tertentu yang bertujuan untuk mengawasi produksi, penjualan, dan harga serta untuk melakukan monopoli terhadap komoditas atau industri tertentu. ${ }^{17}$ Adapun karakteristik kartel dalam hal ini terbagi menjadi 4 (empat) yakni, modus yang dilakukan dengan konspirasi dari beberapa pelaku usaha, kedua yaitu sama-sama sepakat tentang penetapan harga, ketiga agar berjalan efektif untuk dilakukan alokasi terhadap konsumen produksi atau wilayah pemaran, dan keempat adanya perbedaan kepentigan diantara pelaku usaha salah satunya yakni perbedaan biaya. Tindakan praktik seperti ini jelas sangat dilarang untuk dilakukan karena akan berakibat kerugian terhadap konsumen dan terhambatnya pelaku usaha lain yang ingin mencoba melakukan inovasi yang baru dan menawarkan lebih murah dan pelayanan lebih.18

Ketentuan yang diatur di dalam Pasal 11 UU 5/1999 menggunakan prinsip dan pendekatan rule of reason, dilihat dari cara proses pembuktian yang cenderung untuk melihat dan memeriksa alasan-alasan dari pelaku usaha yang melakukan suatu

${ }^{16}$ Supianto, (2013), Pendekatan Per Se Illegal dan Rule Of Reason Dalam Hukum Persaingan Usaha Di Indonesia, Jurnal Rechtens, Vol. 2, No. 1, Juni 2013, h. 45-46.

${ }^{17}$ Susanti Adi Nugroho, (2014), Hukum Persaingan Usaha Di Indonesia (Dalam Teori dan Praktek serta Penerapan hukumnya), Jakarta: Penadamedia Grup, h. 40.

${ }^{18}$ Idang Riyadi dan T.N. Syamsah. (2018). Model Pencegahan Praktik Kartel Impor Daging Sapi Dikaitkan Dengan Daya Beli Masyarakat, Jurnal Living Law, Vol. 10, No. 1, Januari 2018, h. 85. 
perbuatan yang dianggap melawan hukum dengan melakukan praktik monopoli. Hal ini tidak dapat hanya dilakukan dengan pembuktian secara langsung sebagaimana Pasal 42 UU 5/1999 terkait dengan alat bukti dalam penanganan perkara KPPU yakni keterangan saksi, ahli, surat dan atau dokumen, petunjuk serta keterangan pelaku usaha. KPPU harus dapat membuktikan alasan-alasannya terlebih dahulu apakah perjanjian itu mengakibatkan persaingan usaha tidak sehat, jika melihat bukti secara langsung tidak ditemukan atau belum memiliki kebenaran yang kuat maka upaya KPPU dapat melakukan penerapan sistem pembuktian tidak langsung (indirect evidence). ${ }^{19}$

Dalam proses pembuktian kartel, KPPU mempunyai kewenangan untuk meneliti dan/atau menilai surat, dokumen dan/atau alat buki lain dalam pemeriksaan terhadap para pelaku usaha yang diduga melakukan praktik kartel sebagaimana ketentuan Pasal 36 huruf I UU 5/1999. Beberapa pelaku usaha dalam praktiknya sudah mengetahui bahwa dalam melakukan kartel perjanjian harus dilakukan secara rahasia atau diamdiam tanpa diketahui oleh siapapun dan bahkan tanpa perjanjian dapat dilakukan. Sehingga dalam hal ini KPPU sulit untuk menemukan dokumen yang berisi kesepakatan beberapa pelaku usaha terkait dengan kesepakatan harga dan wilayah pemasaran, maka langkah yang harus dilakukan oleh KPPU dengan cara melakukan bukti tidak langsung (indirect evidence). Pengertian bukti tidak langsung (indirect evidence) atau juga disebut (circumstancial evidence) yakni bukti yang secara tidak langsung menggambarkan isi dari perjanjian atau para pihak dalam perjanjian praktik monopoli yang dilakukannya, dalam hal bukti tidak langsung yang dapat dilakukan oleh KPPU yakni bukti komunikasi antar para pelaku usaha yang diduga melakukan praktik kartel dan bukti ekonomi tentang pasar dan perilaku dari para pelaku usaha yang menggunakan kartel tersebut. ${ }^{20}$

Pembuktian menggunakan pembuktian tidak langsung atau juga disebut dalam penanganan kasus kartel di Indonesia digunakan oleh KPPU dengan diaturnya Peraturan Komisi Pengawas Persaingan Usaha Nomor 4 Tahun 2010 tentang Kartel. Adapun dilatar belakang pembentukan peraturan yang dimaksud telah dijelaskan pentingnya pembuktian indirect evidence yang melihat dalam penangan kartel oleh Lembaga Persaingan Usaha yang dibentuk di berbagai negara dunia dan berkembang sangat cepat serta kompleks sehingga keberadaan lembaga persaingan usaha telah disiasati oleh berbagai macam pelaku usaha untuk menghindarkan segala bukti-bukti kartel seperti halnya pertemuan rutin dan perjanjian yang disepakati dalam praktik kartel dan pembuktian lain yang biasa digunakan oleh penegak hukum persaingan usaha ataupun pengadilan negeri maupun Mahkamah Agung. Untuk itu pembuktian tidak langsung diterapkan dalam hal berbagai analisis hukum ekonomi yang akhirnya menjadi suatu bukti kartel yang terindikasi telah menimbulkan kerugian yang besar bagi masyarakat di dalamnya.

\footnotetext{
${ }^{19}$ Rachmadi Usman. (2013). Hukum Persaingan Usaha di Indonesia, Jakarta: Sinar Grafika, h. 285.

${ }^{20}$ Mahmul Siregar. (2018). Bukti Tidak Langsung (Indirect Evidence) dalam Penegakan Hukum Persaingan Usaha di Indonesia, Jurnal Hukum Samudra Keadilan, Vol. 13, No. 2, Juli-Desember 2018, h. 12.
} 
Meskipun pembuktian menggunakan pembuktian tidak langsung dapat dilakukan (indirect evidence) namun sekiranya KPPU wajib berhati-hati dalam melakukan penelitian dan pemeriksaan atas pembuktian tersebut, hal ini disebabkan adanya kecenderungan kelemahan dalam melakukan pembuktian tidak langsung, yang mana alat bukti yang dimaksud tidak dapat menjelaskan secara khusus dan pasti dalam mengungkap kebenaran atas adanya tindakan kartel yang dilakukan oleh beberapa pelaku usaha yang telah terikat dalam suatu perikatan. ${ }^{21}$

Pada persidangan KPPU tentunya pembuktian tidak langsung diajukan bersifat tidak fisik namun hanya kesimpulan dari hal atau peristiwa yang telah dipersidangkan seperti halnya pertimbangan yang dibuat oleh KPPU berdasarkan bukti ekonomi (bukti tidak langsung) berupa data, grafik, dan Analisa statistik. Bukti-bukti ini mungkin bisa saja diterima oleh KPPU namun bagaimana jika pembuktian yang dimaksud diajukan ke Peradilan umum atau Mahkamah Agung, yang tentunya akan kesulitan dalam pembuktian tidak langsung sehingga akan mempengaruhi putusan hakim untuk membatalkan putusan KPPU yang memeriksa beberapa pelaku usaha yang diduga melakukan kartel.

Beberapa kasus kartel yang sama namun justru menghasilkan pertimbangan hukum dan putusan yang berbeda terutama antara KPPU dengan putusan di tingkat pengadilan negeri maupun kasasi Mahkamah Agung yang berbeda pendapat dalam menilai pembuktian yang dikeluarkan oleh KPPU menggunakan Bukti tidak langsung dalam perkara Kasasi Mahkamah Agung Nomor Nomor 582K/PDT.SUS/2011. Perkara dugaan kartel di bidang industri minyak goreng yang dilakukan oleh 21 (dua puluh satu) perusahaan industri minyak goreng. Awalnya perkara ini KPPU dalam persidanganya Nomor 24/KPPU-I/2009, KPPU menggunakan pembuktian tidak langsung (indirect evidence), yang terbagi menjadi 3 (tiga) yakni:

${ }^{21}$ Sunarti Puspita Sari. (Oktober 2017). Proses Pembuktian Kartel dalam Hukum Persaingan Usaha Dengan Menggunakan Alat Bukti Tidak Langsung (Indirect Evidence), JOM Jurnal Hukum, Vol. IV, No. 2, h. 7. 


\begin{tabular}{|c|c|c|}
\hline \multicolumn{3}{|c|}{ Pembuktian Tidak Langsung (Indirect Evidence) oleh KPPU } \\
\hline Bukti Komunikasi & Bukti Ekonomi & Facilitating practices \\
\hline $\begin{array}{l}\text { Berupa adanya pertemuan dan } \\
\text { komunikasi antar pesaing yang } \\
\text { sepakat untuk melakukan } \\
\text { penetapan harga atau pemasaran } \\
\text { terhadap produk barang } \\
\text { dan/atau jasa. Dalam kasus } \\
\text { kartel minyak goreng ini telah } \\
\text { ditemukan adanya komunikasi } \\
\text { baik secara langsung maupun } \\
\text { tidak langsung yang dilakukan } \\
\text { oleh para terlapor dengan } \\
\text { adanya pertemuan dan/atau } \\
\text { komunikasi yang dibahas antara } \\
\text { lain mengenai harga, kapasitas } \\
\text { produk, dan struktur produksi. }\end{array}$ & $\begin{array}{l}\text { Terdapat } 2 \text { (dua) tipe } \\
\text { bukti yang dapat dilihat } \\
\text { dengan adanya stuktur } \\
\text { pasar dan perilaku yang } \\
\text { tercermin dari adanya } \\
\text { price parallelism. }\end{array}$ & $\begin{array}{l}\text { Dilakukan melalui price } \\
\text { signaling dalam } \\
\text { kegiatan promosi dalam } \\
\text { waktu yang tidak } \\
\text { bersamaan } \\
\text { pertemuan serta } \\
\text { komunikasi atau } \\
\text { pesaing } \\
\text { asosiasi. } \\
\text { (Pembuktian melalui } \\
\text { penggabungan antara } \\
\text { bukti komunikasi dan } \\
\text { bukti ekonomi) }\end{array}$ \\
\hline
\end{tabular}

Sumber: Putusan KPPU Nomor 24/KPPU-I/2009

Pembuktian tidak langsung (indirect evidence) digunakan oleh Majelis KPPU dalam memutus perkara atas dugaan kartel minyak goreng, oleh 21 (dua puluh satu) perusahaan industri minyak yang terbukti bersalah melakukan praktik monopoli dengan alasan persaingan dari sisi harga dan terbukti mengakibatkan kerugian konsumen. Konsumen yang berarti masyarakat merupakan kerugian terhadap kepentingan umum mengingat minyak goreng sebagai kebutuhan pokok dan strategis. Adapun KPPU juga memberikan denda terhadap para pelaku usaha sesuai dengan besaran kesalahannya.

Putusan KPPU Nomor 24/KPPU-I/2009 diajukan keberatan oleh para pelaku usaha minyak goreng melalui peradilan umum pada Perkara Nomor 03/KPPUI/2010/PN.JKT.PST dan Mahkamah Agung dalam perkara Nomor 582K/PDT.SUS/2011, yang ternyata tidak sependapat dengan pembuktian tidak langsung (indirect evidence), yang mana majelis Hakim Kasasi sependapat dengan Putusan Judex Facti Pengadilan Negeri Jakarta Pusat terkait dengan adanya dugaan pelanggaran kartel sebagaimana Pasal 11 UU No. 5 Tahun 1999 tidak dapat menerapkan sistem indirect evidence karena bukan merupakan ruang lingkup alat bukti yang diatur di dalam Pasal 42 UU 5/1999 yang disamakan dengan alat bukti petunjuk, Adapun menurut majelis Hakim Kasasi menyatakan bahwa sistem pembuktian indirect evidence bukanlah bukti petunjuk karena petunjuk harus diperoleh dari keterangan saksi, surat maupun keterangan pelaku usaha/terlapor, sedangankan pembuktian tidak langsung didapat dari dugaan, penafsiran atau interpretasi, logika dan asumsi.

Ketentuan tentang alat bukti yang diatur Pasal 42 UU 5/1999 secara eksplisit tidak mengatur tentang pembuktian tidak langsung, sehingga bukan satu-satunya cara untuk membuktikan bahwa para pelaku usaha diduga melakukan praktik monopoli. Perlunya adanya kepastian bagaimana penerapan pembuktian tidak langsung ini diterapkan dan 
digunakan dalam UU 5/1999 tidak hanya untuk KPPU namun juga dalam institusi di Pengadilan Negeri maupun Mahkamah Agung. Salah satu putusan kasasi Mahkamah Agung Nomor 495 K/Pdt.Sus-KPPU/2017, yang justru berbeda pendapat, dalam pertimbangan hukumnya yang menjadi norma baru dalam praktik pembuktian tidak langsung, yang menyatakan di dalam persesengkolan, pembuktian tidak langsung menjadi sangat penting karena pelaku usaha dengan pelaku usaha lain dan pihak lain akan melakukan perjanjian diam/silent agreement, yang diikuti oleh concerted action atau perilaku yang saling menyesuaikan, misalnya penggunaan dan pemanfaatan orang-orang tertentu yang sama.

Berdasarkan adanya inkonsistensi dalam Perkara Kasasi Mahkamah Agung Nomor 582K/PDT.SUS/2011 dengan perkara Kasasi Mahkamah Agung K/Pdt.Sus-KPPU/2017 yang telah mengeluarkan norma hukum baru dalam pembuktian tidak langsung K/Pdt.Sus-KPPU/2017, sekiranya adanya perubahan dalam ketentuan UU No. 5 Tahun 1999 tentang norma hukum pembuktian dan prosedur penyelidikan dan penelitian diperluas dengan melakukan kajian dan perbandingan di negara-negara lain yang sudah jauh lebih dinamis dan tidak kaku dalam menggunakan alat bukti indirect evidence.

Pembuktian dengan menggunakan metode pembuktian tidak langsung, seperti yang telah peneliti uraikan yakni bukti ekonomi dan bukti komunikasi dalam membuktikan adanya terjadi praktik monopoli dalam perkara kartel memiliki tujuan untuk menguatkan sistem pembuktian pada hukum persaingan usaha yang bersifat progresif serta dinamis. Di beberapa pelaku usaha yang memiliki karakter perilaku yang berbeda sehingga sulit tentunya untuk membuktikan, dikaitkan dengan perilaku bisnis setiap pelaku usaha dalam bersaing yang bertujuan untuk mematikan pesaing yang pada akhirnya juga berdampak pada ketugian ekonomi. Tujuan ini praktiknya dilakukan melalui cara-cara curang (unfair) baik secara sendiri maupun terkoordinasi. ${ }^{22}$

Adapun di tingkat peradilan dan Mahkamah Agung agar dapat menerima dan bersifat terbuka sehingga tidak hanya mengacu pada sifatnya pembuktian secara konvensional. Ketentuan alat bukti (indirect evidence) juga dapat dimasukkan sebagai bukti petunjuk dengan diperkuat keterangan ahli yang berkompeten di bidangnya untuk mempermudah penjelasan-penjelasan dugaan praktik monopoli yang sampai saat ini masih terjadi. Selain itu perlunya perluasan kewenangan KPPU dalam melakukan proses pembuktian tidak langsung yang mempunyai kewenangan untuk melalukan penyelidikan dan penyidikan dengan meminta segala dokumen-dokumen, rekamanrekaman bukti komunikasi, dan berkas-berkas pemasaran produk yang mana kewenangan itu sendiri sudah diatur di dalam internal KPPU sebagaimana ketentuan di dalam Peraturan Komisi Pengawas Persaingan Usaha Nomor 4 Tahun 2010 tentang Kartel.

22Anna Maria Tri Anggraini. (2013). "Penggunaan Bukti Ekonomi dalam Kartel Berdasarkan Hukum Pesaingan Usaha". Jurnal Hukum Prioris, Vol. 3 No. 3, Tahun 2013, h. 24. 
B. Kedudukan Alat Bukti Tidak Langsung (Circumstantial Evidence) dalam Undang-Undang No. 5 Tahun 1999 tentang Larangan Praktik Monopoli dan Persaingan Usaha Tidak Sehat

Norma hukum dalam praktik monopoli dan persaingan usaha dalam ketentuan UU 5/1999 masuk dalam ruang lingkup hukum perdata melihat adanya interaksi antara pelaku usaha pesaing di pasar dagang produk barang dan jasa, maka di dalam proses pemeriksaan juga bersifat keperdataan, yang mana Majelis Hakim KPPU hanya menjatuhkan vonis bagi pelaku usaha sebagai terlapor dan juga denda yang harus ditanggungnya. Namun berbeda dengan pembuktian, kedudukan pembuktian yang dicari dalam proses hukum acara persaingan Usaha yang dilakukan oleh KPPU sama seperti pidana yakni untuk mencari kebenaran materiil, dalam hal ini KPPU wajib aktif untuk mencari, menemukan, menganalisis, dan mempertimbangkan buktibukti yang diajukan dalam persidangan KPPU. ${ }^{23}$

Jenis-jenis alat bukti jika peneliti bandingkan baik di dalam Hukum Acara Perdata, Hukum Acara Persaingan Usaha, dan Hukum Acara Pidana, dapat dilihat di dalam tabel di bawah ini:

\begin{tabular}{|l|l|l|}
\hline $\begin{array}{c}\text { Alat Bukti Hukum } \\
\text { Acara Perdata }\end{array}$ & $\begin{array}{c}\text { Alat Bukti Hukum } \\
\text { Acara Persaingan Usaha }\end{array}$ & \multicolumn{2}{c|}{$\begin{array}{c}\text { Alat Bukti Hukum } \\
\text { Acara Pidana }\end{array}$} \\
\hline Alat Bukti dalam & $\begin{array}{l}\text { Alat Bukti dalam Hukum } \\
\text { Hukum Acara Perdata } \\
\text { di dalam Pasal 164 Persaingan Usaha }\end{array}$ & $\begin{array}{l}\text { Ketentuan alat bukti } \\
\text { dalam Hukum Acara }\end{array}$ \\
HIR/284 RBG yakni & UU No. 5 Tahun 1999 & $\begin{array}{l}\text { Pidana diatur di dalam } \\
\text { Pasal 184 Kitab Hukum }\end{array}$ \\
sebagai berikut: & yakni: Keterangan Saksi, & Acara Pidana (KUHAP) \\
Surat-Surat, Saksi- & Keterangan Ahli, Surat & yakni: keterangan saksi, \\
Saksi, Pengakuan, & dan atau dokumen, & keterangan ahli, Surat, \\
Sumpah, Persangkaan & Petunjuk, dan Keterangan & Petunjuk, dan keterangan \\
Hakim. & Pelaku Usaha. & terdakwa. \\
\hline
\end{tabular}

Sumber: Diolah oleh Peneliti

Alat-alat bukti dalam hukum acara persaingan usaha terbatas hanya diatur di dalam Pasal 42 UU 5/1999, sampai saat ini belum adanya aturan baru berkaitan alat bukti di dalam hukum acara persaingan usaha. Ketentuan lebih khusus diatur di dalam Peraturan Komisi Pengawas Persaingan Usaha Nomor 4 Tahun 2010 tentang Kartel. KPPU yang mencari alat bukti menggunakan kewenanganya sebagaiman di dalam UU 5/1999 untuk meminta dokumen baik itu softcopy maupun hardcopy, menghadirkan saksi dan dan melakukan investigasi ke lapangan.

Beberapa kasus yang juga ditangani oleh KPPU dalam dugaan praktik monopoli dengan menggunakan pembuktian tidak langsung (circumstantial evidence/indirect evidence) dapat peneliti uraikan di dalam tabel berikut ini:

23Siti Anisah. (2020). Webinar 20 Tahun KPPU: Tantangan Pembuktian dalam Penanganan Kasus Kartel Circumstantial Evidence dalam Kartel, Yogyakarta: Fakultas Hukum Universitas Islam Indonesia, h. 3. 


\section{Penelitian Kasus Perkara KPPU dalam Sistem Pembuktian (Circumstantial Evidence/ Indirect Evidence)}

\begin{tabular}{|c|c|}
\hline Putusan KPPU Nomor 08/KPPU-I/ 2014 & $\begin{array}{c}\text { Putusan KPPU Nomor } \\
\text { 04/KPPU-I/2016 }\end{array}$ \\
\hline $\begin{array}{l}\text { Dugaan praktik kartel yang dilakukan oleh beberapa } \\
\text { pelaku usaha KPPU oleh para pelaku usaha dan } \\
\text { pesaingnya berkaitan dengan dugaan pelanggaran } \\
\text { kartel dalam industri otomotif terkait kartel ban } \\
\text { kendaraan bermotor roda empat. KPPU melakukan } \\
\text { sistem pembuktian tidak langsung berkaitan dengan } \\
\text { bukti Informasi dalam pertimbangan hukum Majelis } \\
\text { Hakim KPPU menyatakan untuk menghindari } \\
\text { lolosnya praktik persaingan curang, istilah dalam } \\
\text { perjanjian yang dimaksud untuk dibuktikan tidak } \\
\text { hanya untuk tertulis maupun tidak tertulis, namun } \\
\text { juga termasuk tindakan bersama (concertead action) } \\
\text { Walaupun tanpa mengikatkan dirinya satu sama lain. } \\
\text { Tindakan ini dilakukan oleh Negara Australia yang } \\
\text { dilakukan secara bersama acting in concert, yang } \\
\text { dalam membuktikan melihat dari kesepakatan tetapi } \\
\text { ada gejala terpola yang muncul merskipun tidak } \\
\text { terlihat. Majelis hakim KPPU memperluas definisi } \\
\text { perjanjian sebagaaimana Pasal } 1313 \text { KUHPerdata atas } \\
\text { penerapan pembuktian yang berlaku }\end{array}$ & $\begin{array}{l}\text { Dugaan praktik kartel yang } \\
\text { dilakukan oleh Yamaha dan } \\
\text { Honda sesama pesaing atas } \\
\text { penetapan harga kendaraan } \\
\text { bermotor roda dua skutik. } \\
\text { Keterangan ahli berkaitan dengan } \\
\text { sistem pembuktian tidak langsung } \\
\text { (indirect evidence) yang } \\
\text { menyatakan bahwa: } \\
\text { Dalam sistem hukum acara di } \\
\text { Indonesia tidak dikenal sistem } \\
\text { direct evidence dan circumstantial } \\
\text { evidence seperti yang dikenal } \\
\text { dalam hukum persaingan usaha } \\
\text { di AS, Uni Eropa atau } \\
\text { negaranegara maju lainnya alat } \\
\text { buktinya hanya mengenal seperti } \\
\text { saksi, surat petunjuk dan } \\
\text { keterangan pelaku usaha, di pasal } \\
\text { UU 5/1999. }\end{array}$ \\
\hline
\end{tabular}

Sumber: Putusan KPPU No. 08/KPPU-I/2014 dan Putusan KPPU No. 04/KPPU-I/ 2016

Berdasarkan perkara yang ditangani oleh KPPU dalam kasus praktik kartel untuk ban kendaraan roda empat yang dilakukan oleh beberapa perusahaan otomotif ban dalam perkara Putusan KPPU No. 08/KPPU-I/2014 serta dalam Kasus praktik Kartel yang dilakukan oleh dua perusahaan besar kendaraan bermotor yaitu Yamaha dan Honda, menggunakan metode pembuktian tidak langsung (circumstantial evidence/indirect evidence) dikarenakan dalam 2 (dua) kasus tersebut pihak pelaku usaha melakukan praktik monopoli secara diam-diam, dalam aspek hukum perdata perjanjian secara diam-diam juga dapat dilakukan oleh beberapa pihak perusahaan yang melakukan tindakan kartel, sehingga perjanjian yang dibuatnya adalah perjanjian lisan. Perjanjian secara lisan diperbolehkan oleh peraturan perundang-undangan meskipun sulit dalam membuktikannya. Perjanjian secara lisan itu sendiri diatur di dalam Pasal 1 ayat (7) UU 5/1999 terkait pengertian perjanjian yang secara luas menyatakan tidak hanya perjanjian secara tertulis namun juga perjanjian tidak tertulis dapat menjadi pembuktian oleh KPPU untuk menerapkan tindakan sanksi bagi perusahaan yang membuat perjanjian yang dilarang dalam kasus ini praktik kartel.

Ketentuan bukti tidak langsung itu sendiri dalam mengungkap kesalahan dari pelaku usaha dan pesaingnya yang melakukan praktik kartel dapat dilihat dalam Peraturan Komisi Pengawas Persaingan Usaha Nomor 4 Tahun 2010 selain bukti secara langsung yang bersifat otentik namun juga KPPU berkewajiban untuk membuktikan secara tidak langsung (circumstantial evidence), yakni dijelaskan dalam pembuktian perkara kartel yakni alat bukti dokumen atau rekaman kesepakatan 
harga, data perkembang produksi penjualan di beberapa wilayah pemasaran, laba operasional, hasil analisis pengolahan data keuntungan, data laporan keuangan perusahaan, dan kesaksian yang bersifat komunikasi antara peserta kartel, kesaksian pelanggan, karyawan atau mantan karyawan perusahaan yang diduga terlibat kebijakan perusahaan yang didalamnya adanya kesepakatan kartel.

Perkara Kasasi Mahkamah Agung Nomor Nomor 582K/PDT.SUS/2011 telah menolak permohonan kasasi dari KPPU yang menggunakan pembuktian tidak langsung circumstantial evidence/indirect evidence) dikarenakan hanya mengacu pada ketentuan Pasal 42 UU 5/1999, yang semestinya jika Majelis Hakim Kasasi menerapkan ketentuan yang diatur di dalam Peraturan Komisi Pengawas Persaingan Usaha Nomor 4 Tahun 2010, maka dalam proses penyelidikan, penelitian dan pengumpulan alat bukti KPPU telah memenuhi segala prosedur yang diatur apa yang telah dibuatnya.

Kedudukan bukti tidak langsung dalam UU 5/1999 jika menurut KPPU termasuk dalam kelompok bukti petunjuk sehingga hanya bersifat alat bukti tambahan, dalam membuktikan dugaan atas pelanggaran Undang-Undang Persaingan Usaha. Alat bukti tidak langsung yang dilakukan oleh KPPU harus melihat bukti lainya hingga mendapatkan proses suatu kesimpulan atas dugaan kartel. Sehingga tidak memiliki kekuatan hukum apabila alat bukti tidak langsung sebagai alat bukti satu-satunya dalam mempertimbangkan oleh KPPU bahwa para pelaku usaha yang melakukan perjanjian kartel telah melakukan pelanggaran praktik monopoli. ${ }^{24}$

Bukti tidak langsung yang digunakan melalui metode alat bukti ekonomi berupa analisis pasar dan grafik data harga serta bukti komunikasi yang tidak dapat dan dikatakan sama dengan pembuktian langsung (direct evidence) yang mana bukti secara langsung dapat langsung pelaku usaha tersebut melakukan praktik monopoli sebagaimana yang telah dilaporkan oleh KPPU misalkan dalam praktik monopoli adanya perjanjian tertulis dari beberapa kesepakatan dengan perusahaan pesaing untuk menetapkan nilai harga pasar, adanya perjanjian tertulis langsung dapat membuktikan adanya kesalahan para pelaku usaha pesaing melakukan praktik monopoli.

Berbeda dengan alat bukti tidak langsung (circumstantial evidence) yang juga bukti yang tidak secara langsung membenarkan kesalahan para pelaku usaha dalam praktik monopoli, melainkan adalah bukti yang diambil dari bukti-bukti lain yang satu dengan yang lainnya saling bersesuaian sehingga dari bukti-bukti yang berdiri sendiri-sendiri tersebut dapat ditarik sebuah simpulan yang dapat digunakan untuk membuktikan adanya praktik monopoli yang dilakukan oleh pelaku usaha.

Munir Fuady menyatakan bukti circumstantial evidence atau pembuktian tidak langsung perlu mendapatkan relevansi yang rasional dengan dapat menunjukkan adanya penggunaan bukti tersebut dalam proses pengadilan, untuk mendapatkan

${ }^{24}$ Kurniawan. (November 2019). "Kedudukan Bukti Tidak Langsung dalam Penyelesaian Sengketa Kartel di Indonesia", Jurnal Jastiswara, Vol. 34, No. 3, h. 231. 
bukti yang lebih jelas daripada jika tidak digunakan alat bukti tersebut. ${ }^{25}$

Pembuktian tidak langsung (circumstantial evidence/indirect evidence) dalam praktik di pengadilan tidak menjadi bukti yang diutamakan dan digunakan oleh Majelis Hakim baik di tingkat peradilan maupun di Mahkamah Agung, namun hanya dikategorikan sebagai bukti tambahan atau pendukung dari bukti-bukti lain, hal ini diakui dan dinyatakan di dalam praktiknya pada beberapa perkara putusan mahkamah agung, yang menyatakan bukti tidak langsung belum diatur dalam hukum atau peraturan yang berlaku di Indonesia, dan tidak sesuai dengan ketentuan alat bukti sah, sebagaimana yang diatur dalam UU 5/1999.26 Sedangkan pedoman yang diatur di dalam Peraturan Komisi Persaingan Usaha Nomor 4 Tahun 2010 Tentang Kartel. Hanya bersifat internal di dalam KPPU. Sehingga dapat dikatakan kedudukan bukti tidak langsung circumstantial evidence hanya sebagai bukti pendukung bagi hakim atau KPPU untuk mencari kebenaran materiil.

\section{PENUTUP}

KPPU melakukan pembuktian untuk mencari kebenaran materiil atas dugaan praktik monopoli yang dilakukan oleh beberapa pelaku usaha khususnya dalam praktik perjanjian kartel. Pembuktian yang dilakukan KPPU menggunakan pendekatan rule of reason yang tidak langsung menetapkan para pelaku usaha bersalah dalam kartel, namun melihat adanya gejala-gejala dan alasan-alasan timbulnya praktik kartel. Kesulitan dalam mencari bukti secara langsung dalam perjanjian kartel yang dilakukan secara diam-diam, maka upaya yang dilakukan dengan melakukan pembuktian (indirect evident) yang terdiri dari bukti komunikasi dan bukti ekonomi. Dalam praktik peradilan maupun Mahkamah Agung terdapat perbedaan pendapat (dissenting opinion) tentang berlakunya pembuktian (indirecet evident) hal ini dikarenakan hukum nasional belum mengatur keabsahan alat bukti (indirect evident) dalam membuktikan adanya dugaan praktik kartel. Kedudukan alat bukti tidak langsung (indirect evident/circumstantial evidence) seperti bukti komunikasi dan bukti ekonomi dalam proses penegakan hukum pembuktian merupakan ketentuan yang berbeda dibanding dengan alat bukti perdata maupun alat bukti pidana, bahkan ketentuan hukum nasional dalam UU 5/1999 tentang alat bukti tidak langsung juga tidak diatur dalam dalam hukum Acara Persaingan Usaha untuk membuktikan terjadinya praktik monopoli. Namun dalam praktiknya baik dalam KPPU ataupun beberapa putusan baik Peradilan maupun Mahkamah Agung sudah mengakui pembuktian tidak langsung. Meskipun demikian kedudukan bukti tidak langsung bukanlah satu-satunya alat bukti untuk menyatakan bahwa adanya dugaan terjadinya praktik monopoli, pembuktian tidak langsung hanyalah bukti tambahan atau pendukung dari bukti-bukti lainnya yang diatur di dalam Pasal 42 UU 5/1999.

${ }^{25}$ Munir Fuady. (2015). Teori Hukum Pembuktian Pidana dan Perdata, Bandung: Citra Aditya Bakti, h. 5 .

${ }^{26}$ Maria Margaretha Christi Ningrum Blegur Laumuri. (Desember 2018). Pengaruh Penggunaan Indirect Evidence dalam Putusan Komisi Pengawas Persaingan Usaha (Studi Kasus Putusan KPPU Nomor 04/KPPU-I/2016), Jurnal Kertha Patrika, Vol. 40, No. 3, h. 196. 
Menimbang hal tersebut di atas, Pertama diperlukan perubahan pengaturan yang diatur dalam UU 5/1999 tentang prosedur dan alat bukti yang sah terkait bukti komunikasi dan bukti ekonomi, juga memperluas kewenangan KPPU dalam prosedur pembuktian tidak langsung (indirect evident). Kedua, perlu adanya revisi tentang perluasan alat bukti dalam UU 5/1999, karena sistem pembuktian hukum dalam hukum persaingan usaha yang saat ini bersifat dinamis dan progresif melihat perkembangan dan perilaku pelaku usaha yang sangat berkembang dan modern.

\section{DAFTAR PUSTAKA}

\section{Buku dan Jurnal:}

Ali Imron dan Muhamad Iqbal. (2019). Hukum Pembuktian, Tangerang: UNPAM PRESS.

Amiruddin dan Zainal Asikin. (2010). Pengantar Metode Penelitian Hukum, Jakarta: PT Raja Grafindo.

Lilik Mulyadi. (2012). Hukum Acara Pidana Indonesia, Bandung: Citra Aditya Bakti, 2012.

Munir Fuady. (2015). Teori Hukum Pembuktian Pidana dan Perdata, Bandung: Citra Aditya Bakti.

Mustafa Kamal Rokan. (2010). Hukum Persaingan Usaha (Teori dan Praktiknya di Indonesia), Jakarta: RajaGrafindo Persada.

Rachmadi Usman. (2013). Hukum Persaingan Usaha di Indonesia, Jakarta: Sinar Grafika.

Susanti Adi Nugroho. (2014). Hukum Persaingan Usaha di Indonesia (Dalam Teori dan Praktek serta Penerapan hukumnya), Jakarta: Penadamedia Grup.

Anna Maria Tri Anggraini. (2013). Penggunaan Bukti Ekonomi Dalam Kartel Berdasarkan Hukum Pesaingan Usaha, Jurnal Hukum Prioris, Vol. 3 No. 3, Tahun 2013.

Alum Simbolon. (2012). Kedudukan Hukum Komisi Pengawas Persaingan Usaha Melaksanakan Wewenang Penegakan Hukum Persaingan Usaha, Mimbar Hukum, Vol. 23, No. 3, Oktober 2012.

Bastian Nugroho. (2017). Peranan Alat Bukti Dalam Perkara Pidana Dalam Putusan Hakim Menurut KUHAP, Jurnal Yuridika, Vol. 32, No. 1, Januari 2017.

Fira Mubayyinah. (2017). Perbandingan Sistem Hukum Pembuktian Dalam Penanganan Perkara Tindak Korupsi Dengan Perkara Tindak Pidana Lainnya, Al Hikmah Jurnal Studi Keislaman, Vol. 7, No. 1, Maret 2017.

Ibnu Akhyat. (2018). Penggunaan Indirect Evidence (Alat Bukti Tidak Langsung) Dalam Proses Pembuktian Dugaan Praktik Kartel di Indonesia oleh KPPU, Era Hukum, Vol. 16, No. 2, Oktober 2018.

Idang Riyadi dan T.N. Syamsah. (2018). Model Pencegahan Praktik Kartel Impor Daging Sapi Dikaitkan dengan Daya Beli Masyarakat, Jurnal Living Law, Vol. 10, No. 1, Januari 2018.

Kurniawan, (2019), Kedudukan Bukti Tidak Langsung Dalam Penyelesaian Sengketa Kartel Di Indonesia, Jurnal Jastiswara, Vol. 34., No. 3, November 2019.

Made Prasasta Primandhika dan I Gede Artha. (2019). Analisis Penerapan Pendekatan Rule Of Reason dan Per Se Ilegal Terhadap Kasus Kartel di Indonesia, Kertha Semaya: Journal Ilmu Hukum, Vol. 6. No. 7, July 2019.

Mahmul Siregar. (2018). Bukti Tidak Langsung (Indirect Evidence) Dalam Penegakan Hukum Persaingan Usaha di Indonesia, Jurnal Hukum Samudra Keadilan, Vol. 13, No. 2, JuliDesember 2018.

Maria Margaretha Christi Ningrum Blegur Laumuri. (2018). Pengaruh Penggunaan Indirect Evidence dalam Putusan Komisi Pengawas Persaingan Usaha (Studi Kasus Putusan KPPU Nomor 04/KPPU-I/2016), Jurnal Kertha Patrika, Vol. 40, No. 3, Desember 2018. 
Masyelina Boyoh. (2015). Independensi Hakim Dalam Memutus Perkara Pidana Berdasarkan Kebenaran Materiil, Lex Crimen, Vol. 14, No. 4, Juni 2015.

Maya Meilia. (2019). Persaingan Usaha Tidak Sehat di Indonesia Menurut Hukum Ekonomi Islam di Indonesia Menurut Hukum Ekonomi Islam dan Undang-Undang Nomor 5 Tahun 1999 Tentang Larangan Monopoli Dan Persaingan Usaha Tidak Sehat, Jurnal Ekonomi Islam, Vol. 7. No. 1, Januari-Juni 2019.

Meita Fadhilah. (2019). Penegakan Hukum Persaingan Usaha Tidak Sehat Oleh Komisi Pengawas Persaingan Usaha (KPPU) dalam Kerangka Ekstrateritorial, Wawasan Yuridika, Vol. 3, No.1, Maret 2019.

Parida Angriani. (2016). Indikasi Kartel Komunditas Strategis Dalam Perspektif Hukum Persaingan Usaha Tidak Sehat (Studi Kajian Perlindungan Hukum), Dialogia Juridica Jurnal Hukum Bisnis dan Investasi, Vol. 7, No. 2, April 2016.

Rusyadi, Kekuatan Alat Bukti Dalam Persidangan Perkara Pidana, Jurnal Hukum Prioris, Vol. 3, No. 2, April 2016.

Siti Anisah. (2020). Webinar 20 Tahun KPPU: Tantangan Pembuktian Dalam Penanganan Kasus Kartel Circumstantial Evidence Dalam Kartel, Yogyakarta: Fakultas Hukum Universitas Islam Indonesia, 2020.

Sunarti Puspita Sari. (2017). Proses Pembuktian Kartel dalam Hukum Persaingan Usaha dengan Menggunakan Alat Bukti Tidak Langsung (Indirect Evidence), JOM Jurnal Hukum, Vol. IV, No. 2, Oktober 2017.

Supriatna. (2016). Persengkokolan Bisnis Dalam Bentuk Perjanjian Kartel, Positum, Vol. 1., No. 1, Desember 2016.

Udin Silalahi dan Isabella Cynthia Edgina. (2017). Pembuktian Perkara Kartel Di Indonesia Dengan Menggunakan Tidak Langsung (Indirect Evidence) Kajian Putusan KPPU Nomor 17/KPPU-I/2010 dan Nomor 08/KPPU-I/2004 serta Putusan Nomor 294 K/Pdt.Sus/2012 dan Nomor 221 K/Pdt.Sus-KPPU/2016, Jurnal Yudisial, Vol. 10, No. 3, Desember 2017.

Veri Antoni. (2019). Penegakan Hukum Atas Perkara Kartel di Luar Persekongkolan Tender Di Indonesia, Mimbar Hukum, Vol. 31., No. 1, Mei 2019.

Zulhery Artha, (2016), Pencarian Kebenaran Materiil dalam Mengadili Sengketa Wakaf, Jurnal Tarjih, Vol. 13., No. 2, 2016.

\section{Peraturan Perundang-Undangan:}

Kitab Undang-Undang Hukum Perdata

Herzien Inlandsch Reglement (H.I.R.) Reglemet Indonesia Yang Diperbaharui (R.I.B.)

Undang-Undang Nomor 8 Tahun 1981 tentang Kitab Undang-Undang Hukum Acara Pidana.

Undang-Undang Republik Indonesia Nomor 5 Tahun 1999 tentang Larangan Praktek Monopoli dan Persaingan Usaha Tidak Sehat.

Peraturan Komisi Pengawas Persaingan Usaha Nomor 4 Tahun 2010 tentang Kartel.

Putusan Pengadilan :

Putusan Komisi Pengawas Persaingan Usaha (KPPU) Republik Indonesia Perkara Nomor 24/KPPU-1/2009.

Putusan Komisi Pengawas Persaingan Usaha (KPPU) Republik Indonesia Perkara Nomor 08/KPPU-I/ 2014.

Putusan Komisi Pengawas Persaingan Usaha (KPPU) Republik Indonesia Perkara Nomor 04/KPPU-I/ 2016.

Putusan Pengadilan Negeri Jakarta Pusat 03/KPPU-I/2010/PN.JKT.PST.

Putusan Kasasi Mahkamah Agung Republik Indonesia Nomor 582K/PDT.SUS/2011.

Putusan Kasasi Mahkamah Agung Repbublik Indonesia Nomor 1495 K/PDT.SUS/2017. 